\title{
The Role of Internal Control and Firm-Specific Characteristics on Firm Value: Evidence from Indian Financial Services Sector
}

\author{
Anju Kalluvelil Janardhanan $P h D$ \\ Lecturer \\ Crown Institute of Higher Education \\ North Sydney, New South Wales, Australia \\ E-mail: anju.kj@cihe.edu.au \\ Uma V R PhD \\ Associate Professor \\ Department of Commerce \\ CHRIST (Deemed to be University) \\ Bengaluru, Karnataka, India \\ E-mail: uma.vr@,christuniversity.in
}

\begin{abstract}
This research determines the role of firm-specific characteristics such as firm size, firm age, liquidity, firm complexity, board independence, institutional ownership, non-performing assets, annual volatility of stock returns, leverage and internal control represented by Enterprise Risk Management (ERM) and Big4 auditor on the firm value measured using Tobin's Q, Return On Equity (ROE) and Return On Assets (ROA). This proposition is addressed with the sound statistical investigation of 67 companies listed in the NSE financial services sector by utilizing annual panel data for II years from 2007-I7. The important findings of the study are that the purchasers consider firm size, firm age, liquidity, the volatility of stock returns, and non-performing assets. ROA shows that the management has to focus on firm size, firm age, and volatility of stock returns. ROE informs that the investors will look into firm size, firm age, institutional ownership, non-performing assets, leverage, firm complexity, and volatility of stock returns.
\end{abstract}

Keywords: Firm Value, Internal Control, Tobin's Q, ERM, ROA, ROE, Big4 Auditor, Firm-specific Characteristics.

\section{Introduction}

Firm value is considered as a vital aspect in analyzing a company's financial health. It is an estimate of the total value of a company. Firm value is measured using a three-dimensional approach - from the purchasers, investors, and operational perspective (Adetunji \& Owolabi, 2016). Tobin's Q incorporates market performance into the measurement of firm performance and shows the firm's effectiveness from a purchaser's perspective. The Return on Equity (ROE) shows the return that the investors get for their capital investments to the company. From the investor's perspective, it is an essential component that helps in measuring a firm's performance against its competitors. The Return on Assets (ROA) shows the efficiency of a company to utilize its assets to make profits unaffected by management financing decisions. To enhance the firm value, it is imperative to understand the factors that play a major role in affecting it.

The concept of internal control has gained attention among the public and worldwide regulators because numerous international organizations have declined due to incompetent risk management (Beasley, Branson \& Hancock, 20I0). Many businesses have collapsed and the economic crisis in 2008 could be connected with inadequate internal control mechanisms and risk management (McConnell, 2009). Through internal control, an organization diagnoses threats to explore alternatives and alleviate its risks. Consequently, in any dynamic business environment, internal control is a vital and challenging concern for the organization in each sector (Gordon, Loeb \& Tseng, 2009). As per the Committee of Sponsoring Organizations of the Treadway Commission (2004) an essential part of the internal control is enterprise-wide risk management and external audit. The presence of Enterprise Risk Management (ERM) and external audit by Big4 auditors can help the organization in the potential improvement of firm value to recognize and prevent numerous risks and to accommodate sustainability (Beasley, Clune \& Hermanson, 2005). External auditors of a firm will critically review the quality of internal control. Deloitte, $\mathrm{PwC}$, Ernst \& Young, and KPMG are the Big4 auditor firms. A robust internal control mechanism lies in the proper analysis of the enterprise's risk appetite (Walker, Shenkir \& Barton, 2003).

The purchasers will be interested in acquiring a firm with high Tobin's $Q$, the investors will prefer a company with high ROE, and a greater ROA will reveal the managerial efficiency of a firm. The financial services sector contributes $21 \%$ to India's Gross Domestic Product. So, to enhance the firm value, it is essential for the management to know the numerous factors affecting it. 


\section{Review of Empirical Findings \\ 2.I Effect of ERM on Firm Value}

One of the objectives upon the inception of a firm is to create value by giving priority to its owners. It is a reward for their investments in the firm. Studies establish that a reasonable increment of the firm value is the organization's long term objectives. Owners required affirmation upon their investment that they have contributed and return on their investments. The organization will endeavor to expand the firm value, by extending the financial performance. The review of prior studies on ERM and firm value came up with mixed results. The following studies didn't find any evidence that risk management is value-creating. Danisman and Demirel (2019) investigated Turkish non-financial companies for the five years using mixed research methods and established that ERM doesn't influence $\mathrm{Q}$. They identified the reasons as inadequate risk management disclosure, managerial risk version motives, no clarity on risk management concepts, misuse of financial hedging instruments, and no support from management for effective implementation of ERM.

Sayilir and Farhan (2017) focused on 26 firms in the manufacturing industry of Turkey during the period 2008$\mathrm{I} 3$ and regression analysis established that there is no connection between $\mathrm{Q}, \mathrm{ROA}$ and ERM. They mentioned that there was resistance to change, and the organizational structure did not support ERM implementation. The path analysis study conducted by Agustina and Baroroh (2016) from 201 I to 2013 in the Indonesian banking companies revealed that ERM doesn't influence ROE as they consider it as a compliance requirement with banking regulations. Sprčić, Žagar, Šević and Marc (2016) showed that ERM does not add to the Q of an organization in the long term. Regression results supported that the market reaction for the ERM announcement had a positive effect only for a shorter period. The study was conducted from 2003 to 2012 on 258 non-financial US companies. Research conducted in the Netherlands on 39 insurance companies from 2005 to 2008 by Eikenhout (2015) proved that ERM didn't affect ROA and ROE. Further, the results of multiple regression identified the negative impact of ERM on ROA. Laisasikorn and Rompho (20I4) identified that the ERM System and Performance Management System (PMS) have a weak significant correlation with the ROA and ROE in Thailand. Structural Equation Modeling (SEM) technique was used. They found evidence that firms that had ERMS and PMS achieved good financial performance. But as the implementation of ERMS and PMS requires a substantial amount of a firm's resources, it does not generate more financial benefits in the short run.

Manab and Ghazali (2013) were of the view that though ERM affected firm value, it isn't the prime factor that prompted value creation (EPS). The regression results revealed that ERM helped in better corporate governance in the financial companies when compared to non-financial companies. The sample consisted of $4 \mathrm{I} 7$ public listed Malaysian companies. Ballantyne (2013) also supported that ERM adoption isn't related to Q, ROA and ROE. They used mixedmethod research and collected data from I37 public listed companies in the US. Their study identified that the effectiveness of ERM depends on business leadership and cultural integration. Lin, Wen and Yu (20II) observed that insurers who had adopted ERM incurred a decrease of II.I\% in Q and 5.35\% in ROA. They investigated 85 PC insurer firms in the US during 2000-07. The identified that it is because the implementation costs of ERM are higher than the benefits derived from it.

On the other hand, the following studies could substantiate that ERM creates value. Bohnert, Gatzert, Hoyt and Lechner (2019) supported that ERM increased Q. The regression results also showed that companies with ERM had on an average $6.5 \%$ higher Tobin's Q than non-ERM integrated companies. This empirical study focused on 4I European insurance companies from 2007 to 2015. Lechner and Gatzert (2018) regressed I60 German listed firms from 2009 to 2013 and exhibited that firms with ERM had an increase in Q. One of the significant impediments of the examination was the nonappearance of ERM implementation disclosure. Florio and Leoni (2017) believed that firms with more level of ERM practices had more prominent ROA and Q from the financial and market perspective in Italy. They conducted a study on non-financial companies from 201 I to 20I3. The data collected by Ping and Muthuveloo (20I5) through questionnaire and quantitative analysis on 103 public listed Malaysian firms in 2015 showed that the usage of ERM impacted Q. The data was analyzed by using PLS and SEM. Gates, Nicolas and Walker (2012) collected data through a questionnaire in 2004 and conducted Partial Least Squares (PLS) analysis on I50 companies. The Conference Board members in the US. The reflective method suggested that the use of ERM has multifold benefits such as better managerial decisions, risk awareness and enhanced accountability. Studies conducted by McShane, Nair and Rustambekov (2010) in 2008 among US 82 publicly traded insurers showed that ERM positively impacted Q. They also observed that firms with higher ERM ratings did not have any additional increase in $\mathrm{Q}$.

Silva, Silva and Chan (2019) revealed the ERM impacted Q positively in Brazilian stock exchange during 200413. The regression study used the Generalised Linear Model (GLM) and focused on 80 publicly-traded companies listed on the IbrXIOO index. A large portion of the organizations considered ERM as a part of internal control which upgraded the standard of strategic decisions made and subsequently improve firm value. They observed that this could be a reason for the absence of CRO in firms with ERM. As per the regression study done in 68 publicly-traded Taiwanese financial industry between 200I-20I6 by Chen, Chuang, Huang, and Shih (2019), Q of financial companies with ERM was 5.37\% more thanERM financial companies. They also found that ERM improves revenue and creates cost efficiency too. Hoyt and Liebenberg (20II) focused on 275 publicly-traded insurance firms in the US from I995 to 2005 and found that ERM improved Q. The regression coefficient results supported that ERM insurers had approximately $20 \%$ more firm value than non-ERM insurers after controlling endogeneity bias and other determinants of firm value. 


\subsection{Effect of Audit Committee and Big4 auditor on Firm Value}

Without an audit committee (AC), it is complicated for the success of any organization in the current hostile environment (Lloyd \& Fanning, 2007). Independent members in AC were observed to be more accountable and transparent as they are free from management intervention. A large number of members in AC might be ineffective when compared to smaller committees (García, Barbadillo \& Parez, 20I2). AC is crucial to overseeing the risk management systems, and they play a vital role in risk management (Turley \& Zaman, 2004), and they can influence the board for the successful implementation of risk management (Paape \& Speklé, 2012). The AC must elevate corporate governance standards to secure public interest (Vasile $\&$ Croitoru, 2013). External auditors report their opinions on the internal control quality of a firm. More specifically, they examine and express their views on annual accounts, consolidated financial statements, as well as the board of directors and administration of CEO. The panel data regression results of the study conducted by Chan and $\operatorname{Li}(2000)$ in the fortune 200 companies showed that experts and independence of the audit committee increased Q whereas research led by Yermack (I996) revealed a negative connection between AC size and Q of an organization. The study was conducted on 452 large scale US industrial companies from I984-9I. On the other hand, the size of the audit committee revealed a positive relationship with firm value in the study conducted by Szczepankowski (20I2). The results of audit committee activity in 69 Polish public stock companies during 2009-I0 were presented in the study. The Big4 (Deloitte, PwC, Ernst \& Young and KPMG) are classified as excellent audit quality in most of the previous studies. DeAngelo (198I) identified Big4 auditors to have better monitoring power that facilitates greater credibility of the information. This gives positive signals to stakeholders about the goodwill of the company and greater market response from the users of financial statements. Big4 auditors are considered to identify and report any misrepresentation of financial statements diligently (Gounopoulos \& Pham, 2017).

\subsection{Effect of Firm-specific Characteristics on ERM and Firm Value}

Beasley et al. (2005) and Ghosh (2013) revealed that the independence of the board would bring better risk governance and thus enhance the scope of ERM implementation. Florio and Leoni (2017) found that board independence negatively impacts ROA but has a positive impact on $\mathrm{Q}$. The more the number of subsidiaries, the more is the firm complexity. McShane, Nair and Rustambekov (2010) identified a positive impact of firm complexity on firm value. Gordon, Loeb and Tseng (2009) found that firm complexity can influence the relationship between ERM and firm value. Capasso, Gallucci and Rossi (2015) found that firm value is positively related to firm age in the Italian wine industry, which contradicted the findings of Adetunji and Owolabi (2016) and Rajesh Kumar and Sujit (2018) found out that firm size is an essential determinant of firm value. Most prior studies find that size is negatively associated with the firm value (Lang \& Stulz, I994; Sekerci, 20I6; Sayilir \& Farhan, 2017) while studies conducted by (Jin \& Jorion, 2006; Hoyt \& Liebenberg, 20II; Ballantyne, 20I3; Mohamad, 2018) found a positive relationship between firm size and firm value. Florio and Leoni (2017) and Adetunji and Owolabi (2016) identified that firm size is negatively related to $Q$ and has a positive relation to ROA. Institutional investors act as a monitoring agent for a company. The presence of large outside ownership will pave way for the implementation of ERM as they will pressurise the management to publish all the information (Liebenberg \& Hoyt, 2003). Studies conducted by Marcia, Marcus, Saunders and Tehranian (2007), and Chaganti and Damanpour (199I) identified that institutional ownership has a positive impact on firm value. Organizations with higher financial leverage instigate greater deficit risk and thus more significant financial distress. Studies conducted by Hoyt and Liebenberg (20II), McShane, Nair and Rustambekov (20I0), Mohamad (2018) and Adetunji and Owolabi (2016) revealed that leverage negatively impacts firm value while Winarto (20I5) found a positive influence to firm value. Ballantyne (20I3) found that leverage didn't impact firm value. Jin and Jorion (2006), and Sekerci (2016) find that leverage is positively related to firm value. An organization that has a higher volume of cash produced from its internal activity is probably going to have more prominent slack accessible which it can use for ERM implementation. Along these lines, Ghosh (2013) supported that higher liquidity can encourage a firm to embrace ERM Winarto (2015) found liquidity posits a negative impact on firm value while Mohamad (2018) proved a positive influence on firm value. An organization may flag more severe risks connected with its performance due to instability in stock returns. In this way, they might have higher motivating factors to put resources into ERM to minimize the risks which can upset the accomplishment of organizational objectives. Many studies have hypothesized the relationship between the volatility of stock returns and ERM implementation (Liebenberg \& Hoyt, 2003). The volatility of stock returns is negatively related to firm value (McShane, Nair \& Rustambekov, 2010).

\subsection{Research Gap}

Prior literature shows that the relationship of firm value with ERM, Big4 auditor, firm-specific characteristics such as Firm Size, Firm Age, Liquidity, Firm Complexity, Board Independence, Institutional Ownership, Non-Performing Assets, Annual Volatility of stock returns, and Leverage are contentious. The Companies Act 2013 requires each organisation to have a risk management committee and audit committee for better internal control. This cost will influence firm value. So, it is essential to consider the role of internal control and firm-specific characteristics on firm value. Moreover, in emerging economies like India, only a few empirical studies are available on the influence of internal control and firm- specific characteristics on firm value. This investigation along these lines endeavours to fills the gap in the existing empirical literature on Indian financial services from the perspective of purchasers, management and investors. 


\section{Research Objectives}

- To identify the companies which have adopted ERM and Big4 auditor in the Indian financial services sectors.

- To explore the changes in the firm value based on the adoption of ERM during the study period.

- To investigate the changes in firm value based on the Big4 auditors.

- To analyze the impact of the adoption of ERM, the Big4 Auditor and the firm-specific characteristics on firm value.

\section{Hypotheses Development}

The relationships explored in the existing literature were used to formulate the following research hypotheses

- $\mathrm{HO}_{\mathrm{I}}$ - There is no significant difference in Q between ERM and non-ERM observations.

- $\mathrm{HO}_{2}$ - There is no significant difference in ROA between ERM and non-ERM observations.

- $\mathrm{HO}_{3}$ - There is no significant difference in ROE between ERM and non-ERM observations.

- $\mathrm{HO}_{4}$ - There is no significant difference in Q between Big4 and non-Big4 observations.

- $\mathrm{HO}_{5}$ - There is no significant difference in ROA between Big4 and non-Big4 observations.

- $\mathrm{HO}_{6}$ - There is no significant difference in ROE between Big4 and non-Big4 observations.

\section{Conceptual Framework}

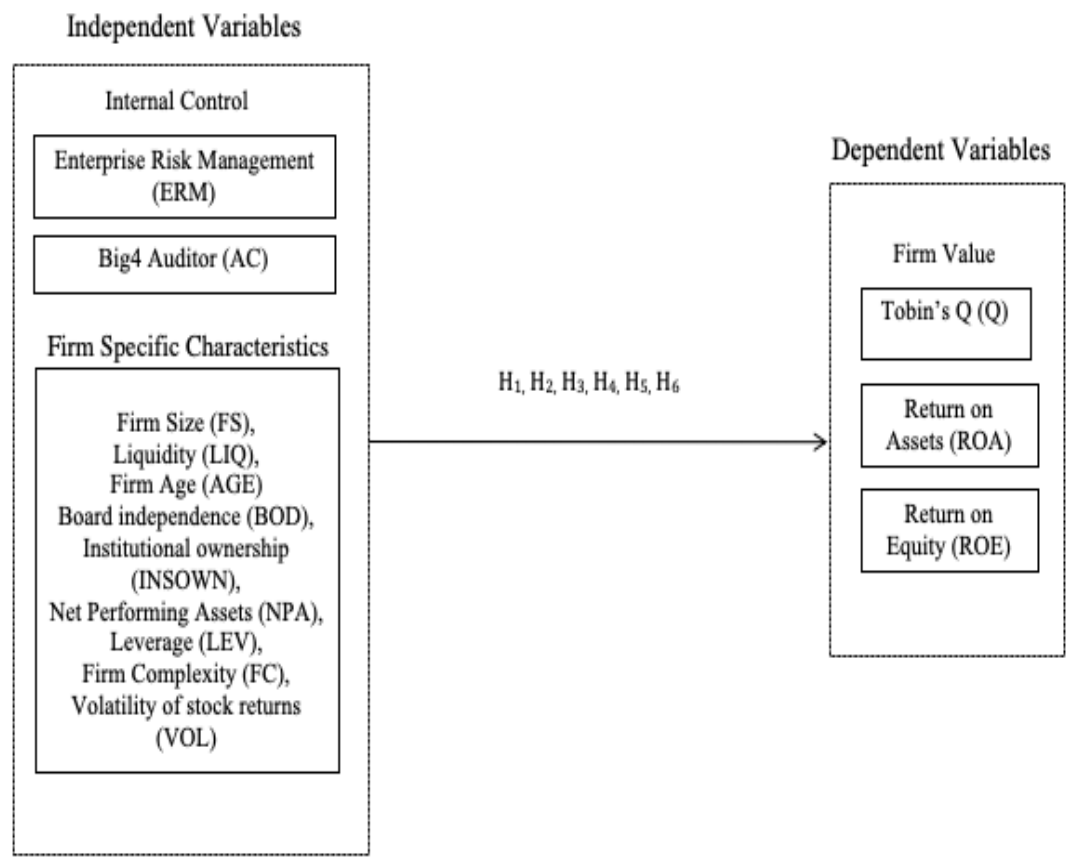

Figure I. Conceptual Framework

\section{Methodology}

- Research design - The research is empirical in nature, quantitative approach, deductive logical reasoning.

- Paradigm - Positivist philosophy.

- Secondary data - Necessary data support was taken from secondary sources of information such as annual reports, company websites, journals, articles and online databases like CMIE PROWESS and Ace Analyser.

- Population Study - Out of the 76 companies in NSE Financial services sector, nine companies were excluded due to the unavailability of data. This population study comprises of 67 companies with 737 firm-year observations.

- The frequency of data - Annual

- Type of data - Panel

- Statistical analysis - Descriptive Statistics such as frequency, percentage, mean and standard deviation, Content Analysis, Trend analysis, One-way ANOVA, Correlation analysis, Hausman test, Multicollinearity test, LikelihoodRatio Test, Wooldridge Test and Panel data regression analysis.

- Statistical software packages - SPSS, EViews and STATA.

- $\quad$ Period of study - This study covers the period of II years from April 2007 to March 2017. 
Table I. Description of variables

\begin{tabular}{|c|c|c|}
\hline Acronym & Type of Variable & Measurement \\
\hline \multicolumn{3}{|c|}{ Dependent Variables } \\
\hline$Q_{i t}$ & Tobin's Q & (Total Assets + Market Capitalization - Net Worth)/ Total Assets \\
\hline$R O A_{\text {it }}$ & Return on Asset & Net Income / Average Total Assets \\
\hline$R O E_{i t}$ & Return on Equity & Net Income / Shareholder's Equity \\
\hline \multicolumn{3}{|c|}{ Independent Variables } \\
\hline$E R M_{i t}$ & $\begin{array}{l}\text { The existence } \\
\text { ERM/RMC/CRO }\end{array}$ & $\begin{array}{l}\text { Dummy variable. Value }=\mathrm{I} \text { if the firm has } \mathrm{ERM} / \mathrm{RMC} / \mathrm{CRO}, 0 \\
\text { otherwise }\end{array}$ \\
\hline$A C_{i t}$ & The existence of Big 4 Auditor & Dummy variable. Value $=\mathrm{I}$ if the firm has Big4 Auditor, 0 otherwise \\
\hline \multicolumn{3}{|c|}{ Firm-Specific Characteristics } \\
\hline$S I Z E_{i t}$ & Firm Size & Natural log of the book value of total assets \\
\hline$A G E_{i t}$ & Firm Age & Number of years from inception to date \\
\hline$L I Q_{i t}$ & Liquidity & Net cash flow from operating activities divided by the total Assets \\
\hline$B O D_{i t}$ & Board independence & $\begin{array}{l}\text { Percentage of independent directors over the total number of directors } \\
\text { on the Board of the company }\end{array}$ \\
\hline INSOWN & Institutional Ownership & Percentage of shares held by institutional investors \\
\hline$N P A_{i t}$ & $\begin{array}{l}\text { The net value of Non- } \\
\text { Performing Assets }\end{array}$ & (Gross NPA's - Provisions) / (Gross Advances - Provisions) \\
\hline$L E V_{\text {it }}$ & Leverage & Total Assets/Net worth \\
\hline$F C_{i t}$ & Firm Complexity & Number of subsidiaries \\
\hline VOLit & Volatility in daily stock returns & (Standard deviation of Daily Returns) $x \sqrt{365}$ \\
\hline
\end{tabular}

$$
\text { Source. Prepared by author }
$$

\section{Model Specification}

The multivariate OLS regression models (general form) developed from Anju and Uma (2017) is used to test the impact of firm value and its determinants. In this study, firm value is measured using Tobin's Q, ROA and ROE as in Adetunji and Owolabi (2016).

Model I

$$
\begin{aligned}
& Q_{i t}=\alpha+\beta_{1} E_{\text {RM }} \text { it }+\beta_{2} \text { AC }_{i t}+\beta_{3} \text { SIZE }_{i t}+\beta_{4} \text { AGE }_{i t}+\beta_{5} \text { LIQ }_{i t}+\beta_{6} \text { BOD }_{i t}+\beta_{7} \text { INSOWN }_{i t}+B_{8} \text { NPA }_{i t}+ \\
& \beta_{9} \mathrm{LEV}_{\text {it }}+\beta_{\mathrm{IO}} \mathrm{FC}_{\text {it }}+\beta_{\mathrm{II}} \mathrm{VOL}_{\text {it }}+\varepsilon_{\text {it }}
\end{aligned}
$$

Model 2

$$
\begin{aligned}
& \mathrm{ROA}_{i t}=\alpha+\beta_{\mathrm{I}} \mathrm{ERM}_{\mathrm{it}}+\beta_{2} \mathrm{AC}_{\mathrm{it}}+\beta_{3} \mathrm{SIZE}_{i \mathrm{t}}+\beta_{4} \mathrm{AGE}_{\mathrm{it}}+\beta_{5} \mathrm{LIQ}_{\mathrm{it}}+\beta_{6} \mathrm{BOD}_{\mathrm{it}}+\beta_{7} \mathrm{INSOWN}_{\mathrm{it}}+\mathrm{B}_{8} \mathrm{NPA}_{\mathrm{it}}+ \\
& \beta_{9} \mathrm{LEV}_{\text {it }}+\beta_{\mathrm{IO}} \mathrm{FC}_{\text {it }}+\beta_{\mathrm{II}} \mathrm{VOL}_{\text {it }}+\varepsilon_{\text {it }}
\end{aligned}
$$

Model 3

$\mathrm{ROE}_{i \mathrm{t}}=\alpha+\beta_{\mathrm{I}} \mathrm{ERM}_{\mathrm{it}}+\beta_{2} \mathrm{AC}_{\mathrm{it}}+\beta_{3} \mathrm{SIZE}_{\mathrm{it}}+\beta_{4} \mathrm{AGE}_{\mathrm{it}}+\beta_{5} \mathrm{LIQ}_{\mathrm{it}}+\beta_{6} \mathrm{BOD}_{\mathrm{it}}+\beta_{7} \mathrm{INSOWN}_{\mathrm{it}}+\mathrm{B}_{8} \mathrm{NPA}_{\mathrm{it}}+$

where,

$$
\beta_{9} \mathrm{LEV}_{\text {it }}+\beta_{\mathrm{IO}} \mathrm{FC}_{\mathrm{it}}+\beta_{\mathrm{II}} \mathrm{VOL}_{\mathrm{it}}+\varepsilon_{\mathrm{it}}
$$

$\alpha=$ Coefficient of intercept (constant)

$\beta_{\mathrm{I}}-\beta_{\mathrm{II}}=$ Regression coefficients

$\varepsilon_{\mathrm{i}}=$ Error term

$\mathrm{t}=$ Sub-indices represent firm and time respectively

\section{Analysis and Interpretation}

\section{I Descriptive Statistics}

The summary statistics of all the I4 variables, i.e., independent, dependent and firm-specific variables, have been shown in

Table 2. It consists of 737 firm-year observations of 67 companies across II years. 
Table 2. Descriptive Statistics of the Variables

\begin{tabular}{|c|c|c|c|c|}
\hline Variable & Mean & Std. Dev. & Min & Max \\
\hline \multicolumn{5}{|l|}{ Dependent variables } \\
\hline Tobin's Q (Q) & 1.40 & 1.40 & 0.02 & I6.99 \\
\hline Return on Assets (ROA) & 2.86 & 6.87 & -45.30 & $\mathrm{I} 20.20$ \\
\hline Return on Equity (ROE) & $\mathrm{I} 4.90$ & 13.22 & -124.65 & I33.7I \\
\hline \multicolumn{5}{|l|}{ Independent variables } \\
\hline Enterprise Risk Management (ERM) & 0.93 & 0.25 & 0.00 & $\mathrm{I} .00$ \\
\hline Big 4 Auditor (AC) & 0.10 & 0.30 & 0.00 & 1.00 \\
\hline \multicolumn{5}{|c|}{ Firm-Specific Characteristics (Control Variables) } \\
\hline Firm Size (SIZE) & 12.50 & 2.07 & 6.65 & 17.12 \\
\hline Firm Age (AGE) & 45.42 & 35.24 & 2.00 & I52.00 \\
\hline Liquidity (LIQ) & -0.10 & 0.90 & $-\mathrm{I} 2.9 \mathrm{I}$ & 5.58 \\
\hline Board Independence (BOD) & 41.07 & 26.19 & 0.00 & 100.00 \\
\hline Institutional Ownership (INSOWN) & 26.88 & 20.05 & 0.00 & 88.39 \\
\hline Non-Performing Assets (NPA) & $\mathrm{I5873.4 \textrm {I }}$ & 50812.88 & 0.00 & 582774.00 \\
\hline Leverage (LEV) & $\mathrm{II} .4 \mathrm{I}$ & 7.76 & 1.00 & 42.67 \\
\hline Firm Complexity (FC) & 4.99 & 7.80 & 0.00 & 62.00 \\
\hline Volatility of Stock Returns (VOL) & 2.46 & I.II & 0.00 & 6.93 \\
\hline
\end{tabular}

\subsection{Findings for Objective $I$}

Content analysis of 737 annual reports and 67 company websites were used to identify the existence of ERM and the presence of Big4 audit firms in the audit committee in the financial services sector. The keywords 'Risk Management', 'Chief Risk Officer', 'Enterprise Risk Management', 'COSO' were searched to identify the existence of ERM and to determine the presence of Big4 auditors, Deloitte, KPMG, Ernst \& Young, and PwC were searched.

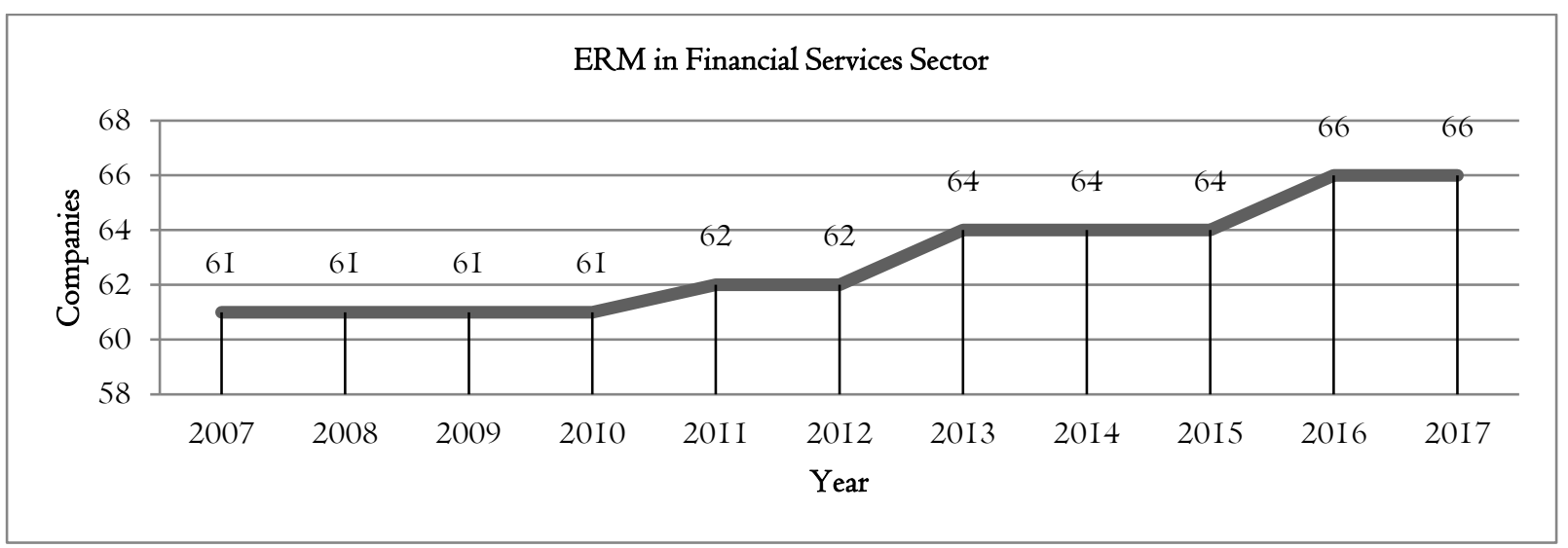

Figure 2. Number of Companies with ERM

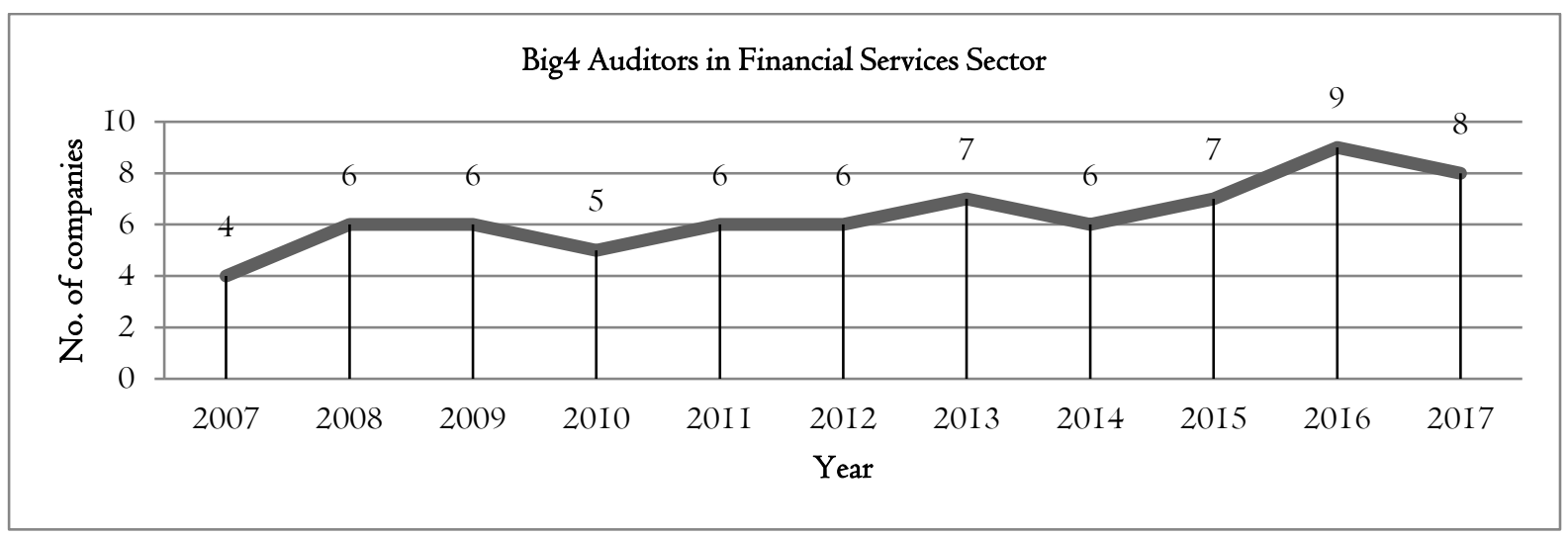

Figure 3. Number of Companies with Big4 auditors 
There is an increase in the existence of ERM during the study period. Sixty-one banks were having ERM for the past II years, i.e., 2007-I7. The Reserve Bank of India had released a notification in 2007 on compliance function in banks which emphasized on enterprise-wide risk management framework. In 2017, 66 banks had ERM. On the other hand, though there is an increasing trend in the presence of Big4 audit firms in the audit committee, only eight companies had a Big4 auditor in 2017.

8.3 Findings for Objective 2

A one-way ANOVA was performed to decide if the firm value measured by $Q$, ROA and ROE differed between ERM (N $=689)$ and non-ERM $(\mathrm{N}=48)$ companies.

Table 3. Descriptive Statistics of Q, ROA, ROE and ERM

\begin{tabular}{|c|c|c|c|c|c|c|c|c|c|}
\hline & & \multirow[t]{3}{*}{$\mathrm{N}$} & \multirow[t]{3}{*}{ Mean } & \multirow{3}{*}{$\begin{array}{c}\text { Std. } \\
\text { Deviation }\end{array}$} & \multirow[t]{3}{*}{ Std. Error } & \multicolumn{2}{|c|}{$95 \%$ Confidence } & \multirow[t]{3}{*}{ Minimum } & \multirow[t]{3}{*}{ Maximum } \\
\hline & & & & & & Lower & Upper & & \\
\hline & & & & & & Bound & Bound & & \\
\hline \multirow[t]{3}{*}{ Q } & 0 & 48 & 1.78 & $\mathrm{I} .40$ & 0.20 & $\mathrm{I} .37$ & 2.18 & 0.33 & 7.55 \\
\hline & $\mathrm{I}$ & 689 & 1.38 & $\mathrm{I} .40$ & 0.05 & $\mathrm{I} .27$ & $\mathrm{I} .48$ & 0.02 & 16.99 \\
\hline & Total & 737 & $\mathrm{I} .40$ & $\mathrm{I} .40$ & 0.05 & $\mathrm{I} .30$ & $\mathrm{I} .5 \mathrm{I}$ & 0.02 & 16.99 \\
\hline \multirow[t]{3}{*}{$\overline{\mathrm{ROA}}$} & 0 & 48 & 6.53 & 17.39 & $2.5 \mathrm{I}$ & I.48 & II.58 & 0.40 & $\mathrm{I} 20.20$ \\
\hline & $\mathrm{I}$ & 689 & 2.60 & 5.36 & 0.20 & 2.20 & 3.00 & -45.30 & 36.30 \\
\hline & Total & 737 & 2.86 & 6.87 & 0.25 & 2.36 & 3.35 & -45.30 & $\mathrm{I} 20.20$ \\
\hline \multirow[t]{3}{*}{ ROE } & 0 & 48 & 17.86 & 19.27 & 2.78 & $\mathrm{I} 2.27$ & 23.46 & 0.48 & I33.7I \\
\hline & $\mathrm{I}$ & 689 & 14.69 & 12.69 & 0.48 & $\mathrm{I} 3.74$ & I5.64 & -124.65 & $63.3 \mathrm{I}$ \\
\hline & Total & 737 & $\mathrm{I} 4.90$ & $\mathrm{I} 3.22$ & 0.49 & I3.94 & $\mathrm{I} 5.85$ & -124.65 & I33.7I \\
\hline
\end{tabular}

Table 4. Comparison of Firm value among ERM and Non-ERM observations

\begin{tabular}{|c|c|c|c|c|c|c|}
\hline $\begin{array}{l}\text { Firm } \\
\text { Value }\end{array}$ & ANOVA & Sum of Squares & $\mathrm{df}$ & Mean Square & $\mathrm{F}$ & Sig. \\
\hline \multirow[t]{3}{*}{$\mathrm{Q}$} & Between Groups & 7.14 & $\mathrm{I} .00$ & 7.14 & 3.65 & $.05^{x}$ \\
\hline & Within Groups & $\mathrm{I} 438.35$ & 735.00 & 1.96 & & \\
\hline & Total & $\mathrm{I} 445.49$ & 736.00 & & & \\
\hline \multirow[t]{3}{*}{$\mathrm{ROA}$} & Between Groups & 691.32 & $\mathrm{I} .00$ & 691.32 & $\mathrm{I} 4.94$ & $.00^{x}$ \\
\hline & Within Groups & 34013.06 & 735.00 & 46.28 & & \\
\hline & Total & 34704.37 & 736.00 & & & \\
\hline \multirow[t]{3}{*}{ ROE } & Between Groups & 451.47 & $\mathrm{I} .00$ & $45 \mathrm{I} .47$ & 2.59 & $.10^{x}$ \\
\hline & Within Groups & I28230.29 & 735.00 & $\mathrm{I} 74.46$ & & \\
\hline & Total & I2868I.75 & 736.00 & & & \\
\hline
\end{tabular}

During the study period,

Note. ${ }^{*}$ Significant at $10 \%$

Source. Authors' Compilation

- There is a difference in Q between ERM and non-ERM observations $[F(\mathrm{I}, 735)=3.65, p=0.05$

- There is a difference in ROA between ERM and non-ERM adoption $[F(\mathrm{I}, 735)=\mathrm{I} 4.94, p=0.00]$

- There is a difference in ROE between ERM and non-ERM observations $[F(1,735)=2.59, p=0.10]$

Of all the three measures, ROA has a higher value than all other measures of firm value. ROA indicates how profitable are the firm's assets in generating income. ERM helps to safeguard the assets and create firm value to their owners. ANOVA table suggests that there is a significant difference in the ROA among the companies that have integrated ERM and not integrated ERM. Non-ERM observations have a higher mean than ERM observations. It means that the companies that do not have ERM in place can generate better ROA. Implementation of ERM will reduce the net income as it involves a large amount of investments. ROE is a measure that indicates how well a company uses its investments in generating earnings. Tobin's $Q$ is the measure of market capitalization on the replacement value of assets. The firm value measured by $Q$ and $R O E$ is different between the ERM and non-ERM observations. It implies that the investors and purchasers of the company consider the presence of ERM before making an investment or calculating the market value of the firm. 


\subsection{Findings for Objective 3}

A one-way ANOVA was administered to determine if the firm value measured by $Q$, ROA and ROE varied among Big4 $(\mathrm{N}=73)$ and non-Big4 $(\mathrm{N}=664)$ companies.

Table 5. Descriptive Statistics of Q, ROA, ROE and Big4

\begin{tabular}{|c|c|c|c|c|c|c|c|c|c|}
\hline & & \multirow[t]{3}{*}{$\mathrm{N}$} & \multirow[t]{3}{*}{ Mean } & \multirow[t]{3}{*}{$\begin{array}{c}\text { Std. } \\
\text { Deviation }\end{array}$} & \multirow[t]{3}{*}{$\begin{array}{l}\text { Std. } \\
\text { Error }\end{array}$} & \multicolumn{2}{|c|}{$\begin{array}{l}\text { 95\% Confidence Interval for } \\
\text { Mean }\end{array}$} & \multirow[t]{3}{*}{ Minimum } & \multirow[t]{3}{*}{ Maximum } \\
\hline & & & & & & Lower & Upper & & \\
\hline & & & & & & Bound & Bound & & \\
\hline \multirow[t]{3}{*}{ Q } & 0 & 664 & $\mathrm{I} .4 \mathrm{I}$ & $\mathrm{I} .46$ & 0.06 & $\mathrm{I} .30$ & 1.52 & 0.02 & 16.99 \\
\hline & $\mathrm{I}$ & 73 & $\mathrm{I} .34$ & 0.67 & 0.08 & I.I8 & 1.50 & 0.03 & $5 . \mathrm{II}$ \\
\hline & Total & 737 & 1.40 & 1.40 & 0.05 & I.30 & I.5I & 0.02 & I6.99 \\
\hline \multirow[t]{3}{*}{$\mathrm{ROA}$} & 0 & 664 & 3.02 & 7.09 & 0.28 & 2.48 & 3.56 & -45.30 & $\mathrm{I} 20.20$ \\
\hline & $\mathrm{I}$ & 73 & $\mathrm{I} .4 \mathrm{I}$ & 4.05 & 0.47 & 0.47 & 2.36 & -23.00 & 6.70 \\
\hline & Total & 737 & 2.86 & 6.87 & 0.25 & 2.36 & 3.35 & -45.30 & $\mathrm{I} 20.20$ \\
\hline \multirow[t]{3}{*}{ ROE } & 0 & 664 & I5.15 & $\mathrm{I3.44}$ & 0.52 & I4.I3 & 16.18 & -124.65 & I33.7I \\
\hline & $\mathrm{I}$ & 73 & $\mathrm{I} 2.57$ & 10.80 & 1.26 & 10.05 & I5.09 & -30.00 & 30.47 \\
\hline & Total & 737 & 14.90 & I3.22 & 0.49 & I3.94 & I5.85 & $-\mathrm{I} 24.65$ & I33.7 I \\
\hline
\end{tabular}

Table 6. Comparison of Firm value among Big4 and Non-Big4 observations

\begin{tabular}{|c|c|c|c|c|c|c|}
\hline $\begin{array}{l}\text { Firm } \\
\text { Value }\end{array}$ & ANOVA & Sum of Squares & $\mathrm{df}$ & Mean Square & $\mathrm{F}$ & Sig. \\
\hline \multirow[t]{3}{*}{$\mathrm{Q}$} & Between Groups & 0.32 & $\mathrm{I}$ & 0.32 & 0.16 & 0.686 \\
\hline & Within Groups & I445.I7 & 735 & 1.97 & & \\
\hline & Total & $\mathrm{I} 445.49$ & 736 & & & \\
\hline \multirow[t]{3}{*}{$\overline{\mathrm{ROA}}$} & Between Groups & $\mathrm{I} 69.58$ & $\mathrm{I}$ & I69.58 & $3.6 \mathrm{I}$ & 0.58 \\
\hline & Within Groups & 34534.8 & 735 & 46.99 & & \\
\hline & Total & 34704.37 & 736 & & & \\
\hline \multirow[t]{3}{*}{ ROE } & Between Groups & 439.17 & $\mathrm{I}$ & 439.17 & 2.52 & 0.113 \\
\hline & Within Groups & I28242.58 & 735 & I74.48 & & \\
\hline & Total & I2868I.75 & 736 & & & \\
\hline
\end{tabular}

During the study period,

Source. Authors' Research

- There is no difference in $Q$ between Big4 and non-Big4 observations $[F(I, 735)=0.16, p=0.686]$

- There is no difference in ROA between Big4 and non- Big4 observations $[F(I, 735)=3.61, p=0.58]$

- There is no difference in ROE between Big4 and non- Big4 observations $[F(I, 735)=2.52, \mathrm{p}=0.1$ I 3$]$

In Table 6 firm value is not different between the Big4 and non-Big4 observations. Only 9\% of the firms (73 firmyear observations) showed the presence of Big4 auditor in the audit committee. It implies that investors and purchasers of the company are not dependent on whether the company has incorporated Big4 in the audit committee for making investment decisions. So, in the long term, when more firms include Big4 audit firms in their audit committee, it may affect firm value.

\subsection{Findings for Objective 4}

8.5.I Correlation Analysis

Pearson Product Moment Correlation has been utilized to gauge the linear connection between the variables.

Table 7. Pearson Correlation Coefficients of the variables

\begin{tabular}{|c|c|c|c|c|c|c|c|c|c|c|c|c|c|c|}
\hline & $\mathrm{Q}$ & ROA & $\mathrm{ROE}$ & ERM & $\mathrm{AC}$ & SIZE & AGE & LIQ & BOD & INS & NPA & LEV & $\mathrm{FC}$ & VOL \\
\hline$Q$ & $\bar{I}$ & & & & & & & & & & & & & \\
\hline $\mathrm{ROA}$ & $0.46^{\text {ta }}$ & $\mathrm{I}$ & & & & & & & & & & & & \\
\hline $\mathrm{ROE}$ & $0.19^{\text {多 }}$ & 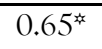 & I & & & & & & & & & & & \\
\hline ERM & $-0.07^{\text {ta }}$ & $-0.14^{*}$ & $-0.06^{\text {th }}$ & $\mathrm{I}$ & & & & & & & & & & \\
\hline $\mathrm{AC}$ & -0.02 & $-0.07^{\text {th }}$ & -0.06 & $0.09^{x+x}$ & $\mathrm{I}$ & & & & & & & & & \\
\hline
\end{tabular}




\begin{tabular}{|c|c|c|c|c|c|c|c|c|c|c|c|c|c|c|}
\hline SIZE & $-0.37^{\star x}$ & $-0.38^{\text {th }}$ & $-0.1 I^{*}$ & $0.26^{* x}$ & -0.02 & I & & & & & & & & \\
\hline AGE & $-0.18^{\text {柿 }}$ & $-0.18^{\text {th }}$ & $-0.07^{\text {柿 }}$ & $0.09^{\text {th }}$ & $-0.14^{*}$ & $0.49^{\text {松 }}$ & I & & & & & & & \\
\hline LIQ & 0.05 & -0.00 & -0.07 & -0.02 & 0.02 & -0.00 & 0.07 & I & & & & & & \\
\hline BOD & $0.07^{\text {tx }}$ & 0.02 & 0.00 & $-0.08^{\text {th }}$ & $0.10^{4 x}$ & $-0.2 I^{*}$ & $-0.28^{\text {th }}$ & $-0.0 \mathrm{I}$ & I & & & & & \\
\hline INS & -0.03 & -0.05 & 0.06 & 0.02 & $0.26^{\text {tx }}$ & $0.38^{\text {t }}$ & $0.06^{*}$ & $0.15^{\text {t }}$ & $0.35^{\text {t* }}$ & I & & & & \\
\hline NPA & $-0.06^{\text {tx }}$ & $-0.09^{\text {市 }}$ & $-0.22^{* x}$ & $0.07^{\text {tx }}$ & -0.05 & $0.40^{* *}$ & $0.22^{4 x}$ & $0.07^{* x}$ & $-0.20^{3 x}$ & 0.05 & I & & & \\
\hline$\overline{L E V}$ & $-0.32^{\text {th }}$ & $-0.32^{*}$ & -0.03 & $0.14^{\text {* }}$ & $-0.18^{\text {th }}$ & $0.66^{*}$ & $0.63^{\text {tx }}$ & $0.10^{* *}$ & $-0.40^{\text {稵 }}$ & -0.01 & $0.24^{*}$ & I & & \\
\hline $\mathrm{FC}$ & $0.14^{* x}$ & 0.00 & $-0.15^{\text {thx }}$ & $-0.0 \mathrm{I}$ & $0.2 \mathrm{I}^{\prime}$ & 0.04 & $-0.19^{\text {市 }}$ & $0.09^{* x}$ & $0.1 I^{*}$ & $0.15^{\prime x}$ & $0.18^{4 x}$ & $-0.40^{\text {玟 }}$ & I & \\
\hline VOL & -0.02 & $-0 . I^{*}$ & $-0.14^{\text {* }}$ & $-0.18^{x}$ & $-0.06^{*}$ & 0.03 & 0.05 & 0.03 & $0.24^{4}$ & $0.20^{\text {松 }}$ & -0.02 & 0.05 & $0.08^{* x}$ & I \\
\hline
\end{tabular}

\section{Note. Results computed using Stata I4; ${ }^{*}$ Significant at I0\%}

\subsubsection{Specification Test}

$$
\text { Source. Authors' compilation }
$$

Table 8. Hausman Test

\begin{tabular}{lccc}
\hline Dependent variable & Chi-Square Statistics & Degree of Freedom & p-value \\
\hline Q & 65.794388 & I I & $0.0000^{\text {** }}$ \\
\hline ROA & 30.2713 & I I & $0.0014^{\text {** }}$ \\
\hline ROE & 97.935982 & I I & $0.0000^{\text {** }}$ \\
\hline
\end{tabular}

Note. denotes statistically significant at I0\% level.

Source. Authors' analysis

Table 8 shows the results of the Hausman test, which rejects the null hypothesis and concludes that the Fixed Effects Model (FEM) is appropriate for each of the models under study.

Table 9. Co-linearity Statistics

\begin{tabular}{lcc}
\hline \multicolumn{2}{c}{ Variance Inflation Factor } & \\
\hline Variable & VIF & Tolerance = I/ VIF \\
\hline Leverage (LEV) & 3.17 & 0.315593 \\
\hline Firm Size (SIZE) & 3.03 & 0.329679 \\
\hline Institutional Ownership (INSOWN) & I.7I & 0.584355 \\
\hline Firm Age (AGE) & I.7I & 0.585256 \\
\hline Board Independence (BOD) & I.5I & 0.660176 \\
\hline Firm Complexity (FC) & I.37 & 0.731093 \\
\hline Non-Performing Assets (NPA) & I.28 & 0.779768 \\
\hline Big4 Auditor (AC) & I.I8 & 0.849524 \\
\hline Volatility of Stock Returns (VOL) & I.I5 & 0.865915 \\
\hline Enterprise Risk Management (ERM) & I.II & 0.900284 \\
\hline Liquidity (LIQ) & I.I & 0.907586 \\
\hline Mean VIF & I.67 & \\
\hline
\end{tabular}

Source. Authors' analysis

Table 9 shows the VIF statistics of the independent variables. The VIF mean is 1.67 , which indicates that there is no multicollinearity.

Table I0. Likelihood-Ratio Test for Panel Level Heteroskedasticity

\begin{tabular}{lccl}
\hline Dependent variable & Chi-Square Statistics & Degree of Freedom & p-value \\
\hline Q & 819.718773 & 66 & $0.0000^{\text {** }}$ \\
\hline ROA & 359.215112 & 66 & $0.0000^{\text {** }}$ \\
\hline ROE & 405.919127 & 66 & $0.0000^{\text {** }}$ \\
\hline
\end{tabular}

Note. significant at I0\%.

Source. Authors' analysis

Table IO confirms the presence of heteroskedasticity at a I\% level of significance, rejecting the null hypothesis. 
Table II. Wooldridge Test for Autocorrelation in Panel Data

\begin{tabular}{lccc}
\hline Dependent variable & F-Statistics & df & p-value \\
\hline $\mathrm{Q}$ & 5.938 & 66 & $0.0175^{\text {** }}$ \\
\hline ROA & I.II & 66 & 0.2958 \\
\hline ROE & 4.539 & 66 & $0.0369^{\text {** }}$ \\
\hline \multicolumn{4}{c}{ Note. ${ }^{* *}$ Significant at I0\% } \\
& Source. Authors' analysis &
\end{tabular}

Table II shows the results of autocorrelation in panel data. The Wooldridge test for autocorrelation rejects the null hypothesis that there is no first-order autocorrelation in model I and model 3 . There is the first-order autocorrelation in model 2. Hence the panel data regression model uses cluster-robust standard errors to control autocorrelation in model I and model 3 .

\subsubsection{Regression Analysis}

Table 12 shows the results of panel data regression estimated using OLS, FEM, and REM models using Q, ROA, and $\mathrm{ROE}$ as the dependent variable. The Hausman test shows a significant p-value that indicates FEM is appropriate for Model I, 2, and 3.

Table I2. Regression results using $Q$ as the dependent variable

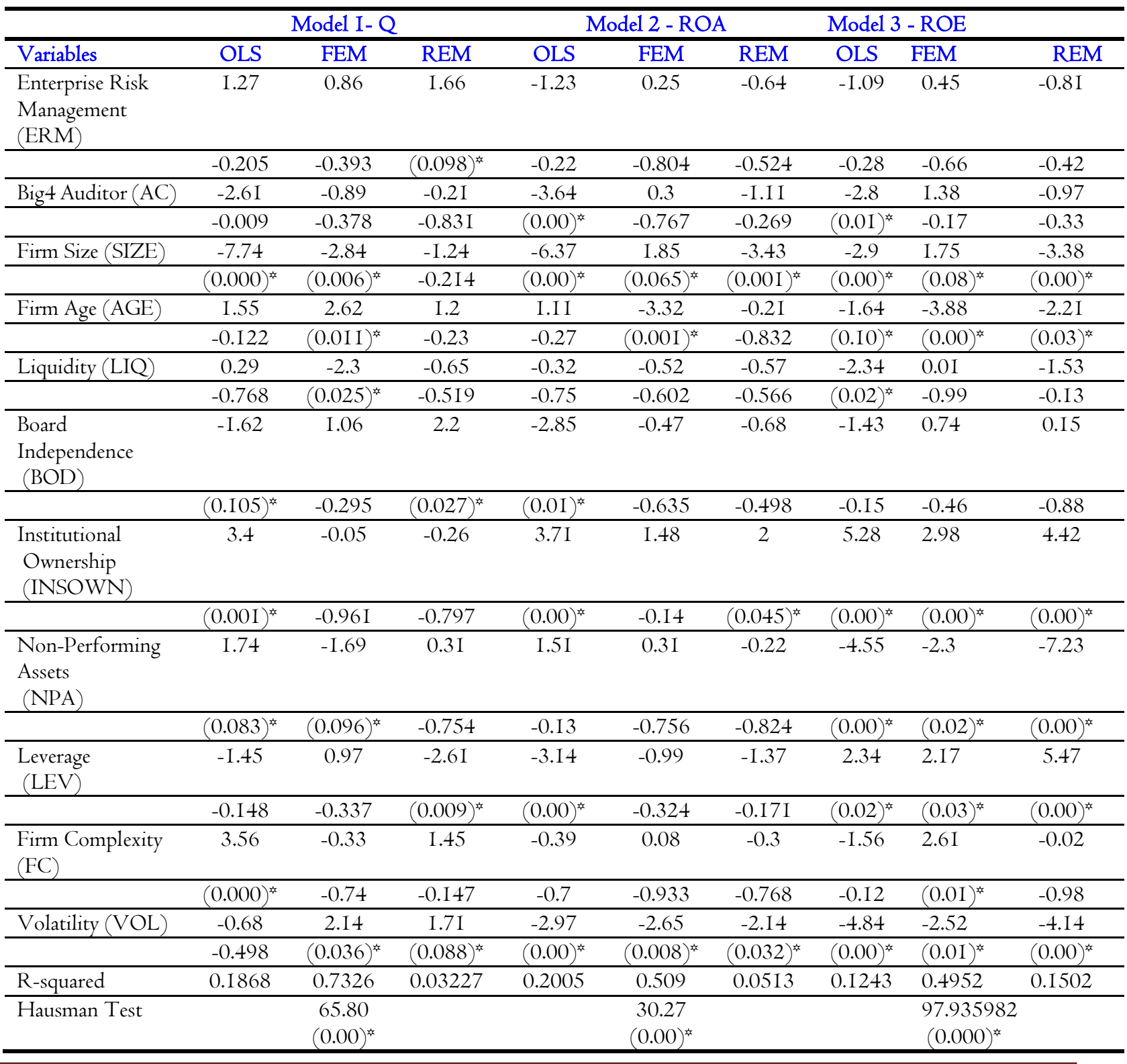




\begin{tabular}{|c|c|c|c|}
\hline F Test & $\begin{array}{c}23.45 \\
(0.00)^{*}\end{array}$ & $\begin{array}{c}8.88 \\
(0.00)^{* *}\end{array}$ & $\begin{array}{l}8.3944 \\
\mathrm{I} 3 \\
(0.000\end{array}$ \\
\hline
\end{tabular}

Note. Results computed using StataI4; p-value is in parenthesis with * Significant at I0\%; OLS

- Ordinary Least Square, FEM - Fixed effects, REM - Random effects.

Source. Authors' analysis

Table 13. Fixed Effect (within) Regression adjusted for robust standard error

\begin{tabular}{lccc}
\hline Variable & Coef. & Robust Std. Err. & p-value \\
\hline Enterprise Risk Management (ERM) & $0.23 \mathrm{I} 4$ & 0.2695 & 0.39 \\
\hline Big4 Auditor (AC) & -0.0667 & 0.0752 & 0.38 \\
\hline Firm Size (SIZE) & -0.3360 & $0.1 \mathrm{I} 82$ & 0.0 I $^{\text {* }}$ \\
\hline Firm Age (AGE) & $0.12 \mathrm{I} 2$ & 0.0463 & 0.0 I $^{\text {* }}$ \\
\hline Liquidity (LIQ) & -0.0992 & 0.0432 & $0.03^{\text {* }}$ \\
\hline Board Independence (BOD) & $0.003 \mathrm{I}$ & 0.0029 & 0.30 \\
\hline Institutional Ownership (INSOWN) & -0.0002 & 0.0043 & 0.96 \\
\hline Non-Performing Assets (NPA) & -1.7800 & 0.0000 & $0.09^{\text {** }}$ \\
\hline Leverage (LEV) & 0.0108 & $0.01 \mathrm{II}$ & 0.34 \\
\hline Firm Complexity (FC) & -0.0045 & 0.0135 & 0.74 \\
\hline Volatility (VOL) & $0.15 \mathrm{I} 6$ & 0.0709 & $0.04^{\text {* }}$ \\
\hline CONSTANT & -0.6843 & 1.0752 & 0.53 \\
\hline
\end{tabular}

Note. ${ }^{*}$ Significant at $10 \%$. Source. Authors’ analysis

Panel Data Fixed Effect Model I is significant and has explanatory power with a good fit as F-statistic $=23.45$ and $\mathrm{p}$-value $=0.000, \mathrm{R}$-squared $=0.73$ indicating that the dependent variables predict $73 \%$ of the variances in $\mathrm{Q}$.

In table I3, the results of the FEM show that there is a significant relationship between the firm size, firm age, liquidity, non-performing assets, volatility and the firm value measured using $\mathrm{Q}$. The results show that the NPA has the highest impact as it decreased the firm value by I.78. If NPA rises, they cannot recover their interest income as borrowers do not pay interests and installments. This creates a negative impression in the minds of the purchasers and reduces the market value of the company. The size of the firm measured by total assets has a negative impact on $Q$ by 0.34 . This is consistent with the findings of Florio and Leoni (2017) and Adetunji and Owolabi (2016). If the total assets are more in a financial services company, it signals the purchasers that the company does not have investment opportunities, so that it is assessed as unfavorable. The volatility of stock returns increases Q by 0.15 from 2007-I7. In this study, there are 372 firm-year observations in the financial services sector with high volatility in daily stock returns that indicate the demand for the firms' share. This creates a positive impression in the minds of the purchasers and influences the market estimation of the company. As the financial service sector firm grows old, it can create a better image in the minds of purchasers and thus improve market value. Firm age has a positive approach to $Q$ throughout the study. It increases Q by 0.I2. Financial firms' liquidity is affected if NPA increases. The results show that liquidity decreases the firm value by 0.09 during the study period. So, to improve liquidity, firms should make regular efforts to reduce bad debt and mobilize additional resources.

Table I4. Fixed Effect (within) Regression using ROA

\begin{tabular}{lccc}
\hline Variable & Coef. & Std. Err. & p-value \\
\hline Enterprise Risk Management (ERM) & 0.3577 & $\mathrm{I} .4432$ & 0.80 \\
\hline Big4 Auditor (AC) & 0.3915 & $\mathrm{I} .318 \mathrm{I}$ & 0.77 \\
\hline Firm Size (SIZE) & 0.9717 & 0.5254 & $0.07^{\text {** }}$ \\
\hline Firm Age (AGE) & -0.4229 & 0.1275 & $0.00^{\text {** }}$ \\
\hline Liquidity (LIQ) & -0.1900 & 0.3643 & 0.60 \\
\hline Board Independence (BOD) & -0.0063 & 0.0132 & 0.64 \\
\hline Institutional Ownership (INSOWN) & 0.0361 & 0.0244 & 0.14 \\
\hline Non-Performing Assets (NPA) & 0.0000 & 0.0000 & 0.76 \\
\hline Leverage (LEV) & -0.0832 & 0.0843 & 0.32 \\
\hline Firm Complexity (FC) & 0.0043 & 0.0503 & 0.93 \\
\hline Volatility (VOL) & -0.6576 & 0.2483 & $0.0 I^{\text {** }}$ \\
\hline CONSTANT & $\mathrm{II.330}$ & 4.0730 & $0.0 \mathrm{I}$ \\
\hline
\end{tabular}

Note. ${ }^{*}$ Significant at I0\%. Source. Authors' Compilation 
Panel Data Fixed Effect Model 2 is significant and has explanatory power with a good fit as F-statistic $=8.88$ and $\mathrm{p}$-value $=0.000$, R-squared $=0.5 \mathrm{I}$ indicating that the dependent variables predict $5 \mathrm{I} \%$ of the variances in ROA.

In table I4, the results of the FEM show a significant relationship between the firm size, firm age, volatility and ROA. As the assets of the firm increases, the management can generate greater profits. That is why firm size has a positive impact on ROA. It increases the firm value by 0.97 during the study period. There are 372 firm-year observations with the high volatility of stock returns indicating that any change in the value of the share will negatively affect the ROA by 0.66 . Firm age has decreased ROA by 0.42 . In this study, there are 470 firm-year observations with less than 45 years of mean industry age. Only when the company grows older, it will be able to understand the business environment better and manage the assets more efficiently. On the contrary, the existence of ERM, the presence of Big4 auditor, board independence, firm complexity, institutional ownership and leverage have an insignificant impact on ROA. It means that the total assets and net income of the company are not affected by the presence of ERM, Big4 audit firms in the audit committee, number of independent directors on the board, number of subsidiaries, the percentage of institutional investors and the percentage of debt-equity for the period 2007 to 2017.

Table I5. Fixed Effect (within) Regression adjusted for robust standard error

\begin{tabular}{lccc}
\hline Variable & Coef. & Robust Std. Err. & p-value \\
\hline Enterprise Risk Management (ERM) & $0.91 \mathrm{I} 8$ & 2.0459 & 0.66 \\
\hline Big4 Auditor (AC) & 1.7912 & 1.2976 & 0.17 \\
\hline Firm Size (SIZE) & 4.1562 & 2.3728 & $0.08^{* *}$ \\
\hline Firm Age (AGE) & -2.0476 & 0.5278 & $0.00^{* *}$ \\
\hline Liquidity (LIQ) & 0.0052 & 0.9743 & 1.00 \\
\hline Board Independence (BOD) & $0.032 \mathrm{I}$ & 0.0432 & 0.46 \\
\hline Institutional Ownership (INSOWN) & 0.1856 & 0.0623 & $0.00^{* *}$ \\
\hline Non-Performing Assets (NPA) & -0.0001 & 0.0000 & $0.03^{* *}$ \\
\hline Leverage (LEV) & 0.4798 & 0.2208 & $0.03^{* *}$ \\
\hline Firm Complexity (FC) & 0.1831 & 0.0700 & $0.01^{* *}$ \\
\hline Volatility (VOL) & -3.1104 & 1.2325 & $0.01^{* *}$ \\
\hline CONSTANT & 50.7192 & 13.0070 & 0.00 \\
\hline
\end{tabular}

Note. ${ }^{*}$ Significant at I0\%. Source: Authors' Compilation

Panel Data Fixed Effect Model 3 is significant and has explanatory power with a good fit as F-statistic $=8.3944$ and $\mathrm{p}$-value $=0.000$, R-squared $=0.49$ indicating that the dependent variables predict $49 \%$ of the variances in $\mathrm{ROE}$.

In table 15, the results of the FEM show that there is a significant relationship between firm size, firm age, institutional ownership, non-performing assets, leverage, firm complexity, volatility, and firm performance measured using ROE. On the contrary, the existence of ERM, the presence of Big4 auditor, board independence, and liquidity has an insignificant impact on firm value. For firm size, the beta values show an increase of 4.16 in ROE during the study period. Investors look forward to investing in firms with a large asset base, as it will generate more returns for their investment. That is why firm size has the highest impact on ROE. There are 372 firm-year observations that high volatility in daily stock returns. It has decreased the ROE of 3.I I. Investors prefer low-volatility stocks to minimize risk in their portfolios. When the company grows old, it can create a better image in the minds of the investor. But here, there are 470 firm-year observations with less than 45 years of mean industry age. Hence it decreases the ROE by 2.05 . There are 407 firm-year observations with low leverage, indicating that there is more equity than borrowings, which signals the investors that the company can generate more income from its investments in the long run. Hence leverage increases ROE by 0.48 during the study period. The number of subsidiaries indicates the company's vision for growth and expansion to the investors. So, these have a positive effect on ROE. During the study period, the percentage of institutional investors and the number of subsidiaries increase the ROE by 0.19 and 0.18 respectively. NPA creates a negative effect on the minds of investors. Hence it decreases ROE.

Table 16. Results of Hypotheses Testing

\begin{tabular}{ccl}
\hline Hypotheses & p-value & Results \\
\hline $\mathrm{HO}_{1}$ & 0.05 & Rejected \\
\hline $\mathrm{HO}_{2}$ & 0.00 & Rejected \\
\hline $\mathrm{HO}_{3}$ & 0.10 & Rejected \\
\hline $\mathrm{HO}_{4}$ & 0.69 & Accepted \\
\hline $\mathrm{HO}_{5}$ & 0.58 & Accepted \\
\hline $\mathrm{HO}_{6}$ & $0.1 \mathrm{I}$ & Accepted \\
\hline
\end{tabular}

Source. Authors' compilation 
The results of hypotheses testing are shown in Table I6. Thus, in the financial services sector, it is evident there are differences in firm value for ERM and non-ERM companies. But on the other side, there is no difference in firm value for Big4 and non-Big4 companies. The firm value measured by $Q$ showed that the purchasers consider firm size, firm age, liquidity, the volatility of stock returns, and non-performing assets. ROA indicated that the management has to focus on firm size, firm age, and volatility of stock returns. ROE pointed out that the investors will look into firm size, firm age, institutional ownership, non-performing assets, leverage, firm complexity. and volatility of stock returns.

\section{Discussion and Conclusions}

This research determined the role of firm-specific characteristics and internal control represented by ERM and big4 auditor on the firm value measured using a three-dimensional approach - from the purchaser, management and investor perspective.

\section{I Purchaser's Perspective}

For ERM, the study reveals that there is an increase in the Beta coefficient, which means the adoption of ERM, increased the $Q$ value by 0.23 . It implies that the existence of ERM will improve the confidence of purchasers in shares of the company and thus boost the market value of the company. The volatility of stock returns increases Q by 0.I5. In this study, there are 372 firm-year observations in the financial services sector with high volatility in daily stock return, which indicates the demand for the firms' share. This creates a positive impression in the minds of the purchasers and thus affects the market value of the company. The findings are consistent with that of Fang, Noe and Tice (2009). As the financial service sector firm grows old, it can create better confidence in the minds of purchasers and thus improve market value. Firm age has a positive approach to Q throughout the study. It increases Q by 0.I2. Leverage has a positive impact on the minds of the purchasers as it helps to expand the firm's asset and generate returns on risk capital. It increases Q by 0.0I. Similarly, as with any other organization, banks with high leverage ratio is viewed as more secure. The bank needs to utilize its cash-flow to provide loans or sell its risky assets or make investments. This will create less impact if, in future, the creditors fail to repay their loans or the economy faces depression. The presence of Big4 audit firms in the audit committee seems to have a negative impact on Q. The huge resource commitment reduces the firm value by 0.07 . It implies that the purchasers consider other factors apart from the audit quality by the Big4 auditors. Financial firms' liquidity is affected if NPA increases. The results show that liquidity decreases the firm value by 0.09 , which is similar to the findings of Winarto (2015). So, to improve liquidity, firms should make regular efforts to reduce bad debt and mobilize additional resources. The size of the firm measured by total assets has a negative impact on Q by 0.34. This is consistent with the findings of Florio and Leoni (2017) and Adetunji and Owolabi (2016). If the total assets are more in a financial services company, it signals the purchasers that the company does not have investment opportunities, so that it is assessed as unfavorable. The results show that the NPA decreased the firm value by I.78. If NPA rises, they cannot recover their interest income as borrowers do not pay interests and installments. This creates a negative impression in the minds of the purchasers and reduces the market value of the company. Results show that the purchaser does not consider the number of independent directors on the board, the number of subsidiaries and the percentage of institutional investors in the financial services sector. So, it does not help to increase the market value of a company measured by $Q$.

\subsection{Management's Perspective}

As the assets of the firm increases, the management can generate greater profits. That is why firm size has a positive impact on ROA. It increases the firm value by 0.97 during the study period. This result is consistent with that of Florio and Leoni (2017) and Adetunji and Owolani (2016). The regression coefficients indicate that the existence of ERM and the presence of Big4 auditors have a positive impact on ROA during the study period. When ERM is in place, the management can anticipate risks, prevent losses and increase profits. Also, the Big4 auditor ensures audit quality. Though the implementation of ERM and Big4 auditor involves huge resource commitment, it is observed that it will help the management to increase ROA in the long run by 0.36 and 0.39 , respectively. On average, institutional investors hold 0.27 of the shares. The institutional investors have more resources than the individual investor. During the study period, institutional investors help to increase ROA by 0.04 . The presence of prudent and effective institutional investors will motivate the management to perform efficiently, which will help to increase the ROA. NPA indicates the inefficiency of management to prevent bad debts. It doesn't seem to affect ROA. 243 firm-year observations have subsidiaries more than the industry mean. It has increased ROA. It shows the management's efficiency to expand and grow. The number of independent directors on the board helps to improve the efficiency of management through better monitoring and governance. There are 330 firm-year observations, which is highly leveraged, indicating that there are more borrowings than equity, which will affect the net income and assets of the firm. Hence leverage decreases ROA by 0.08. Negative operating cash flow indicates the inefficiency of the management in meeting its operating expenses by generating profits from total assets. In this study, liquidity denotes the net cash flow from operating activities divided by the total assets. 278 firm-year observations are denoting negative liquidity. For liquidity, the study reveals that there is a decrease in ROA by 0.19. Firm age has decreased ROA by 0.42 . In this study, there are 470 firmyear observations with less than 45 years of mean industry age. Only when the company grows older, it will be able to understand the business environment better and manage the assets more efficiently. This supports the findings of Capasso et al. (2015), Dogan (2013) and Coad, Segarra and Teruel (20I2). There are 372 firm-year observations with the high volatility of stock returns indicating that any change in the value of the share will negatively affect the ROA by 0.66 . 


\subsection{Investor's Perspective}

For firm size, the beta value shows an increase of 4.16 in ROE. Investors look forward to investing in firms with a large asset base, as it will generate more returns for their investment. That is why firm size has the highest impact on ROE. Though ERM and Big4 auditors do not ensure guaranteed return on equity, it is evident from the results that their presence in the organization gains the trust and confidence of investors. The study period shows it will increase ROE by 0.9I and I.79, respectively. There are 407 firm-year observations with low leverage, indicating that there is more equity than borrowings, which signals the investors that the company can generate more income from its investments in the long run. Hence leverage increases ROE by 0.48 during the study period. The investors look into the number of independent directors on the board and the percentage of institutional investors before investing in the company. It implies the safety of their investments, as there are good governance and monitoring in the firm. The number of subsidiaries indicates the company's vision for growth and expansion to the investors. So, these have a positive effect on ROE. During the study period, the percentage of institutional investors improved the ROE by 0.19. This supported the findings of Masry (2016). Also, the number of institutional investors and the percentage of independent directors on the management board increases the ROE by 0.18 and 0.03 , respectively. The capacity to pay estimated expenses like providing loans or paying debts using liquid assets decides a bank's liquidity. Here liquidity decreases ROE by 0.005 during the study period. Investors will be interested when a bank maintains a liquidity level that allows it to pay unexpected expenses without liquidating other assets. So, a negative operating cash flow indicates the investors that the company doesn't have sufficient liquid assets to meet its operating expenses. NPA creates a negative effect on the minds of investors. Adebisi and Matthew (2015), Sharifi and Akhter (2016) and Nyarko-Bassi (2018) also agreed on the negative effect of NPA on ROE. As the company grows old, it can create a better image in the minds of the investor. But here, there are 470 firm-year observations with less than 45 years of mean industry age. Hence it decreases the ROE by 2.05. This finding is consistent with Susanti and Restiana (2018) and Ilaboya and Ohiokha (2016). 372 firmyear observations have high volatility in daily stock returns. It has decreased the ROE of 3.II. When the value of the share fluctuates erratically with a rapid increase and immediate falls, it is a high stock. Low volatility stocks help to minimize risks in investor's portfolios as it is steady thus investors prefer it.

\section{I0. Implications of the Study}

The findings of this study are more reliable, accurate, and represent all firms in the financial services sector. The results from the analysis respond to the study's research questions and are of particular interest to investors, researchers and practicing managers in the above sector.

- This study helps to understand that the amendments in the Companies Act led to an increase in $Q$ and a decrease in ROA and ROE. Stringent internal control through ERM and Big4 auditor in the Audit committee builds confidence in the purchasers. But the huge resource commitment in implementing ERM and the adoption of Big4 auditors reduce the net income, which affects the returns for management and investors.

- From this study, it is clear that there is an increase in the adoption of ERM from 6I to 66 firms and from 4 to 8 in the adoption of Big4 auditors.

- The outcome of this study explained that are differences in the firm value among companies that have integrated ERM and not integrated ERM. The companies that do not have ERM in place have higher ROA. Implementation of ERM will reduce the net income as it involves a large number of investments. The investors and purchasers of the company do not consider the presence of ERM before making an investment or calculating the market value of the firm.

- The investors and purchasers of the company are not dependent on whether the company has incorporated Big4 in the audit committee for making investment decisions. So, in the long term, when more firms include Big4 audit firms in their audit committee, it may affect firm value.

- The study showed that the age of the firm and the number of subsidiaries creates confidence in the minds of the purchasers and thus influence $\mathrm{Q}$.

- The outcome of this study indicated that the volatility of stock returns and the firm age influenced ROA.

- The results of the study indicated that the firm size, volatility and firm age affected ROE.

- Data from this study shows that NPA has the highest impact on $Q$, and firm size has a major effect on ROA and ROE.

\section{Recommendations}

This study has contributed to the existing literature by identifying the factors that will impact firm value from three dimensions - purchaser, management and investor in the financial services sector.

- NPA had the highest impact on firm value (Q). To build the confidence of a prospective purchaser, the bankers have to focus on stringent credit policies and debt collection policy to reduce the bad debts. The firm value of the banks will increase if there are fewer bad debts written off from the profits of the banks.

- The companies should invest in ERM even it involves large investment as it helps to increment firm value (Q, ROA and ROE).

- The purchaser, management and investor are interested in a firm with a huge asset base. Hence, every firm should try to increase its size as it helps to improve firm value. 
- The review done by Big4 auditor helps to enhance the credibility of financial statements, which in turn improve the report quality. It increases the firm value (ROA and ROE) from the management and investor perspective.

\section{I2. Limitations}

- This research study is restricted to companies in the NSE Financial Services during the period 2007-2017 only.

- The findings are based on the financial statements and annual reports published by the organizations.

- The dichotomous ERM variable neglects to measure the varying level of ERM implementation across organizations.

\section{I3. Scope for Further Research}

- A prospective direction for future investigations would be to extend this study to different sectors or stock exchanges of other countries or different period as well. It will help to check the validity of the findings in this study.

- Future research could include data from organization surveys and spotlight on developing an ERM index to measure the level of ERM implementations in organizations.

\section{References}

Adebisi, J. F., \& Matthew, O. B. (2015). The impact of non-performing loans on firm profitability: A focus on the Nigerian banking industry. American Research Journal of Business and Management, I(4), I-7. Retrieved from https://www.arjonline.org/papers/arjbm/vI-i4/I.pdf

Adetunji, O. M., \& Owolabi, A. A. (2016). Firm performance and its drivers: How important are the industry and firm-level factors?. International Journal of Economics and Finance, 8(II), 60-77. Retrieved from https://ideas.repec.org/a/ibn/ijefaa/v8y20I6iI Ip60-77.html

Agustina, L., \& Baroroh, N. (20I6). The relationship between enterprise risk management (ERM) and firm value mediated through financial performance. Review of Integrative Business and Economics Research, 5( I), I28-I38. Retrieved from https://sibresearch.org/uploads/3/4/0/9/34097I80/riber_hI5-08I_I28-I38.pdf

Anju, K. J., \& Uma, V.R. (2017). The determinants of firm value from enterprise risk management perspective: A conceptual model. Journal of Management Research, I7(4), I94-203. Retrieved from http:/ / www.indianjournals.com/ijor.aspx?target $=$ ijor:jmr\&volume $=17 \&$ issue $=4$ \&article $=002$

Ballantyne, R. (2013). An empirical investigation into the association between enterprise risk management and firm financial performance (Doctoral dissertation). Retrieved from ProQuest Central; ProQuest Dissertations \& Theses Global. (Order No. 355726I)

Beasley, M. S., Branson, B. C., \& Hancock, B. V. (2010). Are you identifying your most significant risks? Results from a COSO-sponsored survey show that companies need to do a better job in this area. Strategic Finance, 92(5), 2935. Retrieved from https://search.proquest.com/docview/807506272 ?accountid=38885

Beasley, M. S., Clune, R., \& Hermanson, D. R. (2005). Enterprise risk management: An empirical analysis of factors associated with the extent of implementation. Journal of Accounting and Public Policy, 24(6), 52I-53I. http://dx.doi.org/I0.I0I6/j.jaccpubpol.2005.I0.00Is

Bohnert, A., Gatzert, N., Hoyt, R. E., \& Lechner, P. (2019). The drivers and value of enterprise risk management: Evidence from ERM ratings. The European Journal of Finance, 25(3), 234-255. http://dx.doi.org/I0.I080/I35I847X.20I8.I5I43I4

Capasso, A., Gallucci, C., \& Rossi, M. (2015). Standing the test of time: Does firm performance improve with age? An analysis of the wine industry. Business History, 57(7-8), 1037-53. Retrieved from https://search.proquest.com/docview/I7I I052563? accountid $=38885$

Chaganti, R., \& Damanpour, F. (I99I). Institutional ownership, capital structure, and firm performance. Strategic Management Journal, I2(7), 479-49I. https://doi.org/I0.I002/smj.4250I20702

Chan, K. C., \& Li, J. (2008). Audit committee and firm value: evidence on outside top executives as expert-independent directors. Corporate Governance: An International Review, I6(I), I6-3I. http://dx.doi.org/I0.I I I I/j.I4678683.2008.00662.x

Chen, Y. L., Chuang, Y. W., Huang, H. G., \& Shih, J. Y. (2019). The value of implementing enterprise risk management: Evidence from Taiwan's financial industry. The North American Journal of Economics and Finance, I-35. https://doi.org/I0.1016/j.najef.2019.02.004

Coad, A., Segarra, A., \& Teruel, M. (2012). Like milk or wine: Does firm performance improve with age?. Structural Change and Economic Dynamics, 24, I-I7. http://dx.doi.org/I0.I0I6/j.strueco.2012.07.002

Committee of Sponsoring Organizations of the Treadway Commission. (2004). Enterprise risk management: Integrated framework. Retrieved from https://www.coso.org/documents/Framework\%20Reference\%20Secured.pdf

Danisman, G. O., \& Demirel, P. (2019). Corporate risk management practices and firm value in an emerging market: A mixed methods approach. Risk Management, 2I(I), I9-47.

DeAngelo, L. E. (198I). Auditor size and audit quality. Journal of Accounting and Economics, 3(3), I83-199. Retrieved from http:/ / citeseerx.ist.psu.edu/viewdoc/download?doi=IO.I.I.858.456\&rep=repI\&type $=$ pdf

Dogan, M. (2013). Does firm size affect the firm profitability: Evidence from Turkey data of 200 companies active in the Istanbul Stock Exchange between 2008-20II. Research Journal of Finance and Accounting, 4(4), 53-59. Retrieved from https://pdfs.semanticscholar.org/5360/29a44ed8dd384cbcde67f9d60bcI0cf5c775.pdf 
Eikenhout, L. C. A. (20I5). Risk management and performance in insurance companies (Master's thesis, University of Twente, Enschede, Netherlands). Retrieved from http://essay.utwente.nl/66625/I/Eikenhout_MA_MB.pdf

Fang, V. W., Noe, T. H., \& Tice, S. (2009). Stock market liquidity and firm value. Journal of Financial Economics, 94(I), I50. Retrieved from https://search.proquest.com/docview/23I704237 ?accountid=38885

Florio, C., \& Leoni, G. (2017). Enterprise risk management and firm performance: The Italian case. The British Accounting Review, 49(I), 56-74. Retrieved from http://translateyar.ir/wp-content/uploads/2019/01/632.pdf

García, L.S., Barbadillo, E. R., \& Pérez, M. O. (2012). Audit committee and internal audit and the quality of earnings: Empirical evidence from Spanish companies. Journal of Management Governance, I6(2), 305-33I. Retrieved from https://search.proquest.com/docview/928013904/99F64CB35D63495FPQ/I ?accountid=38885

Gates, S., Nicolas, J. L., \& Walker, P. L. (2012). Enterprise risk management: A process for enhanced management and improved performance. Management Accounting Quarterly, I3(3), 28-38. Retrieved from https://search.proquest.com/docview/I030081882?accountid=38885

Ghosh, A. (2013). An empirical investigation into enterprise risk management in India. Indian Accounting Review, Indian Accounting Association Research Foundation, I7 (I), I-25.

Gordon, L. A., Loeb, M. P., \& Tseng, C. (2009). Enterprise risk management and firm performance: A contingency perspective. Journal of Accounting and Public Policy, 28(4), 30I-327. http://dx.doi.org/I0.I0I6/j.jaccpubpol.2009.06.006

Gounopoulos, D., \& Pham, H. (2017). Credit ratings and earnings management around IPOs. Journal of Business Finance \& Accounting, 44(I), I54-I95. https://doi.org/I0.I I I I/jbfa.I2228

Hoyt, R. E., \& Liebenberg, A. P. (201 I). The value of enterprise risk management. Journal of Risk and Insurance, 78(4), 795-822. Retrieved from http://outsourcerm.com/pdf_files/the_value_of_erm.pdf

Ilaboya, O. J., \& Ohiokha, I. F. (2016). Firm age, size and profitability dynamics: a test of learning by doing and structural inertia hypotheses. Business and Management Research, 5(I), 29-39. Retrieved from https://oer.sau.edu.ng/uploads/journals/firm-age-size-and-profitability-dynamics-a-test-of-learning-by-doingand-structural-inertia-hypotheses.pdf

Jin, Y., \& Jorion, P. (2006). Firm value and hedging: Evidence from US oil and gas producers. The Journal of Finance, 6I(2), 893-919. Retrieved http:/ / citeseerx.ist.psu.edu/viewdoc/download?doi=IO.I.I.505.3789\&rep=repI\&type $=$ pdf

Rajesh Kumar, B., \& Sujit, K. S. (2018). Determinants of dividends among Indian firms-An empirical study. Cogent Economics \& Finance, 6(I), I423895.

Lang, L. H., \& Stulz, R. M. (I994). Tobin's q, corporate diversification, and firm performance. Journal of Political Economy, IO2(6), I248-I280. Retrieved from https://search.proquest.com/docview/I954I68I0?accountid=38885

Laisasikorn, K., \& Rompho, N. (20I4). A study of the relationship between a successful enterprise risk management system, a performance measurement system and the financial performance of Thai listed companies. The Journal of Applied Business and Economics, I6(2), 81-92. Retrieved from https://search.proquest.com/docview/I545871970?accountid=38885

Lechner, P., \& Gatzert., N. (2018). Determinants and value of enterprise risk management: Empirical evidence from $\begin{array}{lllll}\text { Germany.European } & \text { Journal }\end{array}$ http://dx.doi.org/I0.I080/I35I847X.2017.1347100

Liebenberg, A. P. and Hoyt, R. E. (2003). The determinants of enterprise risk management: Evidence from the appointment of chief risk officers. Risk Management and Insurance Review, 6(I), 37-52. Retrieved from https://search.proquest.com/docview/209605386?accountid=38885

Lin, Y., Wen, M. and Yu, J. (20II). Enterprise risk management: Strategic antecedents, risk integration and performance. SSRN Electronic Journal, I-48. http://dx.doi.org/I0.2139/ssrn.I62934I

Lloyd, K. and Fanning, J. (2007). The audit committee in the age of risk. Financial Executive, 23(2), 54- 56.

Retrieved from https://search.proquest.com/docview/208915728? accountid=38885

Manab, N. A., \& Ghazali, Z. (20I3). Does enterprise risk management create value? Journal of Advanced Management Science, I(4), 358-362. Retrieved https://pdfs.semanticscholar.org/0782/2dfd3790bc2a00f00713e5b6a329b89b7c69.pdf

Marcia, M. C., Marcus, A. J., Saunders, A., \& Tehranian, H. (2007). The impact of institutional ownership on corporate operating performance. Journal of Banking \& Finance, 3I(6), I77I-1974. Retrieved from https://search.proquest.com/docview/I94897657 accountid $=38885$

Masry, M. (2016). The impact of institutional ownership on the performance of companies listed in the Egyptian

stock market.IOSR Journal of Economics and Finance (IOSR-JEF), 7, 5-I5. Retrieved from http://www.academia.edu/download/43042469/The_Impact_of_Institutional_Ownership_on_the_Performa nce_of_Companies_Listed_In_the_Egyptian_Stock_Market.pdf

McConnell, P. (2009). Prime loss: A case study in operational risk. Journal of Risk Management in Financial Institutions, 3(I), 84-I04.

McShane, M. K., Nair, A., \& Rustambekov, E. (2010). Does enterprise risk management increase firm value?. Journal of Accounting,

Auditing \& Finance, 26(4),
64I-658. 
https://www.researchgate.net/profile/Michael_Mcshane3/publication/228205I0I_Does_Enterprise_Risk_ Management_Increase_Firm_Value/links/55a97I ef08aea3d086803f9b/Does-Enterprise-Risk-ManagementIncrease-Firm-Value.pdf

Mohamad, N. E. A. (2018). Does working capital relevant to enhancing Malaysia's government-linked company (GLC) value?. Global Business \& Management Research, IO(3), 418-428. Retrieved from https://search.proquest.com/docview/2159617982 ?accountid=38885

Nyarko-Baasi, M. (2018). Effects of non-performing loans on the profitability of commercial banks- A case of some selected banks on the Ghana stock exchange. Global Journal of Management and Business Research, I8(2), 39-47. Retrieved from https://www.journalofbusiness.org/index.php/GJMBR/article/view/2456/2357

Paape, L., \& Speklé, R. F. (20I2). The adoption and design of enterprise risk management practices: An empirical study. European Accounting Review, 2I(3), 533-564. Retrieved from http://ssrn.com/abstract=I658200

Ping, T. A., \& Muthuveloo, R. (2015). The impact of enterprise risk management on firm performance: Evidence from Malaysia. Asian Social Science, $I I(22), \quad$ I49-I59. Retrieved from https://pdfs.semanticscholar.org/07ee/4ad033f7aIf8e067063a0e8deef8Iff636b8.pdf

Sayilir, Ö., \& Farhan, M. (20I7). Enterprise risk management and its effect on firm value in Turkey. Journal of Management Research, $\quad$ (I), 86-99. $\quad$ Retrieved from http://www.macrothink.org/journal/index.php/jmr/article/view/IOI24/8472

Sekerci, N. (2016). Does enterprise risk management create value for firms?. In T. J. Andersen (Ed.), The Routledge Companion to Strategic Risk Management (pp. 409-440). Routledge.

Sharifi, O., \& Akhter, J. (2016). Effect of non-performing assets on the profitability of public sector banks of India. International Journal of Engineering and Management Research, 6(5), 383-388.

Silva, J. R., Silva, A. F. D., \& Chan, B. L. (2019). Enterprise risk management and firm value: Evidence from Brazil. Emerging Markets Finance and Trade, 55(3), 687-703.

Sprčić, D. M., Žagar, M. M., Šević, Ž., \& Marc, M. (2016). Does enterprise risk management influence market value- A long-term perspective. Risk Management, I8(2-3), 65-88.

Susanti, N., \& Restiana, N. G. (2018). What's the best factor in determining firm value?. Jurnal Keuangan dan Perbankan, 22(2), 30I-309. Retrieved from https://media.neliti.com/media/publications/26085I-whats-thebest-factor-to-determining-fir-5aI3f005.pdf

Szczepankowski, P. (2012). Audit committee practice in the Polish stock companies. Present situation and development perspectives. Business, Management and Education, IO(I), 50-65.

Turley, S., \& Zaman, M. (2004). The corporate governance effects of audit committees. Journal of Management and Governance, 8(3), 305-332.

Vasile, E., \& Croitoru, I. (2013). Corporate governance in the current crisis. Internal Auditing \& Risk Management, 8(2), I-II.

Walker, P. L., Shenkir, W. G., \& Barton, T. L. (2003). ERM in practice. Internal Auditor, 60(4), 5 I-55.

Winarto, J. (2015). The determinants of manufacturer firm value in Indonesia stock exchange. International Journal of Information, Business and Management, $7(4), \quad 323-349 . \quad$ Retrieved from http://ijibm.site666.com/IJIBM_Vol7No4_Nov20I5.pdf\#page=328

Yermack, D. (1996). The higher market valuation of companies with a small board of directors. Journal of Financial Economics, $\quad 40(2), \quad$ I85-2I2. from https://search.proquest.com/docview/23176I585? accountid=38885

\section{Copyrights}

Copyright for this article is retained by the author(s), with first publication rights granted to the journal. This is an openaccess article distributed under the terms and conditions of the Creative Commons Attribution license (http://creativecommons.org/licenses/by/4.0/). 